\title{
Bacteroides oris and Bacteroides buccae, New Species from Human Periodontitis and Other Human Infections
}

\author{
L. V. HOLDEMAN, W. E. C. MOORE, P. J. CHURN, AND J. L. JOHNSON \\ Department of Anaerobic Microbiology, Virginia Polytechnic Institute and State University, Blacksburg, \\ Virginia 24061
}

\begin{abstract}
Bacteroides oris and $B$. buccae, two new species isolated from periodontal pockets and the superficially cleaned tooth surface coronal to the gingival margin, from various types of human infections, and from chicken intestinal contents are described. They were obligately anaerobic, gram-negative, nonpigmenting, nonmotile, non-spore-forming rods that did not grow well in $10 \%$ bile and that fermented carbohydrates. Although we had previously identified many of these strains as members of $B$. ruminicola subsp. brevis biovar (biotype) 3 (Holdeman et al. [ed.], Anaerobe Laboratory Manual, 4th ed., 1977), in the present study, we found that the strains had no deoxyribonucleic acid homology with the type strains of $B$. ruminicola subsp. ruminicola or $B$. ruminicola subsp. brevis. The strains also had no deoxyribonucleic acid homology with the type strain of $B$. oralis. ATCC 27518, which we deposited as representative of human isolates of $B$. ruminicola subsp. brevis biovar 3 , is now identified as a strain of $B$. oris. The type strains of $B$. oris and $B$. buccae are $B$. oris ATCC 33573 and $B$. buccae ATCC 33574, respectively.
\end{abstract}

During our studies of anaerobic bacteria isolated from human clinical infections and normal floras, we isolated a number of strains of nonpigmenting, saccharolytic bacteroides resembling Bacteroides ruminicola. Many of these strains had the characteristics Bryant et al. (1) described for $B$. ruminicola subsp. brevis biovar (biotype) 3. The description of $B$. ruminicola subsp. brevis biovar 3 in the Virginia Polytechnic Institute Anaerobe Laboratory Manual, 4th ed. (6), was based on results we had obtained from characterization of 50 of these strains, mostly from clinical infections (jaw, chin, and neck wounds [10 strains]; abdominal wounds or peritoneal fluid [8 strains]; blood [2 strains]; spinal fluid [1 strain]; miscellaneous [8 strains]). Strain VPI 7649, isolated from a human wound, was deposited in the American Type Culture Collection, Rockville, Md. (ATCC 27518), to represent this group of strains isolated from humans. We have subsequently isolated more than 100 similar strains from human mouths, mostly from the gingival sulci of sites with periodontitis. Deoxyribonucleic acid (DNA) homology studies were initiated to determine the genetic relatedness of the isolates from human infections to $B$. ruminicola, to other similar normal flora isolates, and to one another. Strains from normal floras included M. P. Bryant's rumen isolates and strains from normal human flora (sputum, bowel, nasopharynx) and the intestinal tracts of chickens. We had previously reported that the human strains are not related to $B$. ruminicola, as determined by DNA homology studies (P. Churn and J. L. Johnson, Abstr. Annu. Meet. Am. Soc. Microbiol. 1980, C40, p. 281), and we described two homology groups, which we called groups D1A-1A (Bacteroides D6) and D3A-6 (Bacteroides D-8) (W. E. C. Moore and L. V. Holdeman, Abstr. Annu. Meet. Am. Soc. Microbiol. 1980, C41, p. 281). In this paper, we report the results of DNA homology studies and the phenotypic characteristics of these two homology groups, and we propose two new species, B. oris and B. buccae.

\section{MATERIALS AND METHODS}

Strains. The strains used in the DNA homology studies and their sources are listed in Table 1. For the homology studies, we selected strains from different sources to obtain information concerning the diversity of natural habitats of these species.

Experimental methods. The prereduced media and the methods used to determine the phenotypic reactions of the strains have been described previously (6) Susceptibilities to chloramphenicol $(12 \mu \mathrm{g} / \mathrm{ml})$, clindamycin $(1.6 \mu \mathrm{g} / \mathrm{ml})$, erythromycin $(3 \mu \mathrm{g} / \mathrm{ml})$, penicillin $\mathrm{G}(2 \mathrm{U} / \mathrm{ml})$, and tetracycline $(6 \mu \mathrm{g} / \mathrm{ml})$ were determined by the broth-disk method of Wilkins and Thiel (14). Polyacrylamide gel electrophoresis (PAGE) patterns of soluble cellular proteins were determined as described by Moore et al. (13).

DNA isolation. The organisms were grown in a medium prepared as described previously (3) and containing mineral salts, $1 \%$ Pepticase, $0.5 \%$ yeast extract, $1 \%$ dehydrated brain heart infusion broth (Difco Laboratories, Detroit, Mich.), $1 \%$ glucose, 
$0.03 \%$ cysteine, $0.03 \%$ sodium formaldehyde sulfoxalate, $0.01 \%$ heme, and $0.05 \mathrm{M}$ potassium phosphate buffer ( $\mathrm{pH} \mathrm{7.0)}$. At the time of inoculation, $10 \mathrm{ml}$ of $10 \%$ sterile $\mathrm{NaHCO}_{3}$ was added to each liter of medium. Flasks containing 1.0 or 2.5 liters of medium were inoculated with 10 to $20 \mathrm{ml}$ of an overnight culture grown in chopped meat-carbohydrate medium (6) and incubated for 18 to $24 \mathrm{~h}$ at $37^{\circ} \mathrm{C}$. The harvested cells were suspended in a $0.15 \mathrm{M} \mathrm{NaCl}-0.01 \mathrm{M}$ ethylenediaminetetraacetic acid salt solution $(\mathrm{pH} \mathrm{8.0)}$. We lysed the cells by adding sodium dodecyl sulfate to a final concentration of $1 \%$. After a preliminary extraction with chromatography-grade phenol, high-molecular-weight DNA (for in vitro labeling) was isolated by the method of Marmur (11). Other DNA preparations were isolated by a hydroxyapatite procedure ( 8 ).

$\mathbf{G}+\mathbf{C}$ content of the DNA. Thermal melting points were used to determine the guanine-plus-cytosine $(\mathrm{G}+\mathrm{C})$ contents of the DNA preparations $(9,12)$.

Preparation of labeled DNA. The high-molecularweight DNA (diluted to $200 \mu \mathrm{g} / \mathrm{ml}$ ) was nicked by being incubated for $1 \mathrm{~min}$ with $0.1 \mu \mathrm{g}$ of electrophoretically purified deoxyribonuclease (Sigma Chemical Co., St. Louis, Mo.). The deoxyribonuclease was then inactivated by being heated at $65^{\circ} \mathrm{C}$ for $10 \mathrm{~min}$. The nicked DNA $(10 \mu \mathrm{g} / \mathrm{ml})$ was labeled with $\left[{ }^{3} \mathrm{H}\right]$ thymidine $5^{\prime}$-triphosphate by a nick translation method (8). The specific activity of the labeled DNA preparations was about $100,000 \mathrm{cpm} / \mu \mathrm{g}$.

DNA homology experiments. Homology experiments were done by using a variation of the $\mathrm{S} 1$ nuclease procedure described by Crosa et al. and by Johnson ( 2 , 8). The reassociation mixtures contained $10 \mu \mathrm{l}$ (ca. $0.025 \mu \mathrm{g})$ of labeled DNA, $50 \mu \mathrm{l}(30 \mu \mathrm{g})$ of unlabeled DNA, and $50 \mu \mathrm{l}$ of $0.88 \mathrm{M} \mathrm{NaCl}-10^{-3} \mathrm{M} \mathrm{N}$-2-hydroxyethylpiperazine- $N^{\prime}$-2-ethanesulfonic acid (HEPES) buffer ( $\mathrm{pH} 7.0)$. Just before each experiment, the labeled DNA needed for the experiment was denatured by being heated in a boiling water bath for $5 \mathrm{~min}$. The reaction vials were incubated for $16 \mathrm{~h}$ at $61^{\circ} \mathrm{C}$ for labeled DNA from reference strain D1 A-1 A and $63^{\circ} \mathrm{C}$ for labeled DNA from reference strain D3A-6.

Unlabeled DNA was either denatured and fragmented homologous or heterologous bacterial DNA or native fragmented salmon sperm DNA. Reaction vials containing native salmon sperm DNA were used to measure the amount of self-renaturation of labeled DNA during the incubation period.

\section{RESULTS AND DISCUSSION}

The $\mathrm{G}+\mathrm{C}$ content and DNA homology results for the strains tested and for the type strains of some other Bacteroides species are presented in Tables 1 and 2. Variable phenotypic characteristics of the strains are presented in Table 3, and PAGE patterns are shown in Fig. 1.

Strains in these homology groups have been confused with $B$. oralis by many researchers because growth was inhibited by $10 \%$ bile. Historically, $B$. oralis was thought to be the most commonly encountered species (in humans) of saccharolytic nonpigmenting bacteroides that did not grow well in bile. Strains selected for study differed from $B$. oralis by their fermenta- tion of pentoses, which $B$. oralis strains do not ferment (10). Although characteristics of these human strains most closely resembled the characteristics described earlier for $B$. ruminicola (1), the strains are distinct from $B$. ruminicola, as determined by DNA homology studies (Table 2).

Strains of homology groups D1A-1A and D3A-6 are obligately anaerobic, nonmotile, nonspore-forming, gram-negative rods that produce succinate and acetate from fermentation of glucose and therefore are members of the genus Bacteroides (7). Because these groups are distinct from phenotypically similar species of $\mathrm{Bac}$ teroides, as determined by DNA homology results, we consider them distinct species for which we propose the names $B$. oris and $B$. buccae. Descriptions of the two proposed species are as follows.

Bacteroides oris (or' is. L. gen. n. oris of the mouth [referring to a major natural habitat of the species]). B. oris cells are obligately anaerobic, non-spore-forming, nonmotile, gram-negative rods. In peptone-yeast extract-glucose (PYG) broth cultures, cells were 0.5 to 0.8 by 0.8 to 2.6 $\mu \mathrm{m}$ and were arranged in pairs and short chains (Fig. 2). In supplemented brain heart infusion agar roll tubes (5), subsurface colonies were 1 to $2 \mathrm{~mm}$ in diameter, lenticular, and translucent. On anaerobically incubated streak tubes or blood agar plates, surface colonies were 0.5 to $1.0 \mathrm{~mm}$ in diameter, circular with an entire edge, low convex, translucent to semiopaque, white to buff, shiny, and smooth. There was no action on rabbit blood or egg yolk agar (6). Cultures did not grow on the surface of blood agar plates incubated in air enriched with carbon dioxide to $10 \%$.

After incubation at $37^{\circ} \mathrm{C}$ for $24 \mathrm{~h}$ in prereduced broth media, cultures were uniformly turbid with a smooth sediment. After incubation for 3 to 5 days, the $\mathrm{pH}$ in media containing a fermentable carbohydrate generally ranged as follows: 4.5 to 4.9 in carbohydrates fermented by all strains and 5.0 to 5.6 in media with sugars that were not fermented by all strains (Table 3 ).

All strains fermented dextrin, fructose, glucose, lactose, maltose, mannose, raffinose, starch, and sucrose; all hydrolyzed esculin and starch; all produced an acid curd in milk. None of the strains fermented erythritol, inositol, mannitol, melezitose, sorbitol, or trehalose; none digested milk or meat; none reduced nitrate; none produced indole or catalase. Most strains did not grow in PYG broth containing $10 \%$ bile; when growth in bile did occur, it was markedly inhibited and delayed. Heme was highly stimulatory for growth of the type strain and was required for growth of some strains.

Acids produced in PYG broth cultures (in 
TABLE 1. $\mathrm{G}+\mathrm{C}$ content, DNA relatedness, and sources of strains of $B$. oris nov, sp. and $B$. buccae nov. sp.

\begin{tabular}{|c|c|c|c|c|}
\hline \multirow{2}{*}{$\begin{array}{c}\text { Unlabeled } \\
\text { DNA from } \\
\mathrm{VPI}^{a} \text { strain } \\
\text { no.: }\end{array}$} & \multirow{2}{*}{$\begin{array}{l}\mathrm{G}+\mathrm{C} \\
\text { content } \\
\text { of DNA } \\
(\mathrm{mol} \%)\end{array}$} & \multicolumn{2}{|c|}{ \% DNA homology to: } & \multirow[b]{2}{*}{ Source (supplier [strain no.]) } \\
\hline & & $\begin{array}{l}\text { D1A-1A } \\
\text { (B. oris) }\end{array}$ & $\begin{array}{c}\mathrm{D} 3 \mathrm{~A}-6 \\
(\text { B. buccae })\end{array}$ & \\
\hline D1A-1A & 42 & $(100)$ & 10 & Gingival sulcus, moderate periodontitis \\
\hline D10A-3. & 43 & 80 & 8 & Tooth surface ${ }^{b}$, severe periodontitis \\
\hline D10A-5... & 43 & 82 & 7 & Same sample as D10A-3 \\
\hline D16B-10 . & 45 & 79 & & Gingival sulcus, moderate periodontitis \\
\hline D21A-8....... & 45 & 88 & 6 & Gingival sulcus, juvenile periodontitis \\
\hline D21B-16...... & 43 & 89 & 7 & Gingival sulcus, juvenile periodontitis \\
\hline D22B-2 . & 45 & 88 & 9 & Gingival sulcus, juvenile periodontitis \\
\hline D23B-27. & & 98 & 7 & Gingival sulcus, juvenile periodontitis \\
\hline $\mathrm{D} 27 \mathrm{~A}-15 \ldots \ldots$ & 45 & 77 & 9 & Tooth surface, severe periodontitis \\
\hline D27B-27...... & & 80 & & Gingival sulcus, severe periodontitis \\
\hline D28C-8A $\ldots \ldots$ & 45 & 84 & 2 & Tooth surface, severe periodontitis \\
\hline D33A-1 $\ldots \ldots \ldots$ & 45 & 81 & 3 & Gingival sulcus, juvenile periodontitis \\
\hline D33A-14....... & & 84 & & Same sample as D33A-1 \\
\hline$D 33 A-30 \ldots \ldots$ & 45 & 88 & 4 & Same sample as D33A-1 \\
\hline D34A-2 $\ldots \ldots \ldots$ & 44 & 79 & 3 & Gingival sulcus, severe periodontitis \\
\hline $\mathrm{E} 1 \mathrm{H}-3 \ldots \ldots \ldots$ & & 87 & 7 & $\begin{array}{l}\text { Gingival sulcus, experimental gingivitis } \\
\text { (11th day without brushing) }\end{array}$ \\
\hline 1277 & 45 & 66 & 1 & Chicken cecal contents \\
\hline $1790 \ldots \ldots \ldots$ & 46 & 80 & 2 & Chicken large intestinal contents \\
\hline $5963 \ldots \ldots \ldots$ & 43 & 58 & 1 & $\begin{array}{l}\text { Neck drainage (D. W. Lambe, Jr. }{ }^{c} \\
[\mathrm{~N}-798-70 \mathrm{~B}])\end{array}$ \\
\hline 7309. & 45 & 81 & 3 & $\begin{array}{l}\text { Wound following rupture of common carotid } \\
\text { (D. W. Lambe, Jr. [N87-72D]) }\end{array}$ \\
\hline $8146 \ldots \ldots \ldots$ & 44 & 76 & 13 & Bronchus (D. Blazevic ${ }^{d}$ [N16-0856]) \\
\hline $9050 \mathrm{D} \ldots \ldots \ldots$ & 46 & 73 & 6 & Sinus aspirate, sinusitis (reference 4 ) \\
\hline D3A-6....... & 50 & 5 & $(100)$ & Gingival sulcus, moderate periodontitis \\
\hline D2B-25A $\ldots \ldots$ & & & 76 & Gingival sulcus, moderate periodontitis \\
\hline D2B-29B $\ldots \ldots$ & & & 99 & Same sample as D2B-25A \\
\hline D3A-20A $\ldots \ldots$ & & 2 & 101 & Same sample as D3A-6 \\
\hline D36D-13...... & & & 88 & Gingival sulcus, severe periodontitis \\
\hline D54C- $6 \ldots \ldots \ldots$ & & & 86 & Tooth surface, severe periodontitis \\
\hline $\mathrm{E} 1 \mathrm{H}-22 \ldots \ldots \ldots$ & & 1 & 88 & $\begin{array}{l}\text { Gingival sulcus, experimental gingivitis } \\
\text { (11th day without brushing) }\end{array}$ \\
\hline $6199 \ldots$. & & & 88 & Pleural fluid (D. W. Lambe, Jr. [N-907-70]) \\
\hline $6232 \ldots \ldots \ldots$ & 52 & 10 & 83 & Human feces \\
\hline $6404 \ldots \ldots \ldots \ldots$ & 52 & 5 & 85 & Human feces \\
\hline $8733 \ldots \ldots \ldots$ & & 0 & 70 & Human cervix (B. Malone $e^{e}$ [268(1)]) \\
\hline $11107 \ldots \ldots \ldots$ & & 26 & 82 & Gum ulcer drainage (W. Franklin $\left.{ }^{f}[\mathrm{~S} 2]\right)$ \\
\hline $11236 \ldots \ldots \ldots$ & & & 88 & Sewage digestor (J. Althaus $\left.{ }^{g}[\mathrm{D} 46]\right)$ \\
\hline
\end{tabular}

${ }^{a}$ VPI, Virginia Polytechnic Institute and State University.

${ }^{b}$ The tooth surface sample was taken coronal to the gingival margin after superficial cleaning of the surface with sterile toothpicks.

${ }^{c}$ East Tennessee State University, Johnson City.

${ }^{d}$ University of Minnesota, Minneapolis.

${ }^{e}$ Florida State Department of Health and Rehabilitative Services, Jacksonville.

$f$ Toxicology Research Laboratories, Jefferson, Ark.

${ }^{g}$ University of Illinois, Urbana-Champaign.

meq/100 $\mathrm{ml}$ of culture) were acetic (1 to 2 ) and succinic (7 to 8 ). Very small amounts of isobutyric and isovaleric acids were detected in some cultures. No hydrogen was detected in the headspace gas from PYG broth cultures.

The type strain and $50 \%$ of the other strains were susceptible to all five antibiotics tested (chloramphenicol, clindamycin, erythromycin, penicillin $G$, and tetracycline). Fifty percent of the strains were resistant to $2 \mathrm{U}$ of penicillin $\mathrm{G}$ per $\mathrm{ml}$, and $20 \%$ of the strains were resistant to 6 $\mu \mathrm{g}$ of tetracycline per $\mathrm{ml}$.

The $\mathrm{G}+\mathrm{C}$ content of the DNA of the type strain was $42 \mathrm{~mol} \%$ and ranged from 42 to 46 mol\% among the strains tested.

The type strain is ATCC $33573(=$ VPI D1A1A), isolated from the gingival sulcus of a person with moderate periodontitis.

Strains of this species have been isolated from human periodontal flora, from systemic human 
TABLE 2. DNA homology reactions of type strains of B. oris, B. buccae, B. oralis, and B. ruminicola

\begin{tabular}{lccc}
\hline \multicolumn{1}{c}{ Unlabeled DNA from: } & $\begin{array}{c}\mathrm{G}+\mathrm{C} \\
\text { content } \\
\text { of DNA } \\
(\mathrm{mol} \%)\end{array}$ & $\begin{array}{c}\text { \% DNA homology to: } \\
\text { ATCC 33573 } \\
\text { (B. oris })\end{array}$ & $\begin{array}{c}\text { ATCC 33574 } \\
(\text { B. buccae })\end{array}$ \\
\hline $\begin{array}{l}\text { B. oris VPI D1 A-1A } \\
\text { (= ATCC 33573) }\end{array}$ & 42 & $(100)$ & 10 \\
$\begin{array}{l}\text { B. buccae VPI D3A-6 } \\
\text { (= ATCC 33574) }\end{array}$ & 50 & 5 & $(100)$ \\
$\begin{array}{l}\text { B. oralis ATCC 33269 } \\
\text { B. ruminicola subsp. ruminicola } \\
\text { VPI 0051B (= ATCC 19189) }\end{array}$ & 44 & 4 & 1 \\
$\begin{array}{l}\text { B. ruminicola subsp. brevis } \\
\text { VPI 0050 (= ATCC 19188) }\end{array}$ & 47 & 6 & 3 \\
\hline
\end{tabular}

infections, and from the large intestines of chickens. In addition to the sources given in Table 1, human isolates (identified by PAGE patterns) have been obtained from face, neck, and chest abscesses and drainages; abdominal wound drainages and peritoneal fluid; blood; and spinal fluid. Strain VPI 7649 (= ATCC 27518, originally deposited as a representative of $B$. ruminicola subsp. brevis biovar 3 ) is a strain of $B$. oris.

Bacteroides buccae (buc' cae. L. gen. n. buccae of the mouth [referring to a major natural habitat of the species]). B. buccae cells are obligately anaerobic, non-spore-forming, nonmotile, gram-negative rods. In PYG broth cul- tures, cells were 0.3 to 0.6 by 0.8 to $3.5 \mu \mathrm{m}$ and occurred singly, in pairs, or occasionally in short chains (Fig. 3). In supplemented brain heart infusion agar roll tubes (5), subsurface colonies were 1 to $2 \mathrm{~mm}$ in diameter, lenticular, and translucent. On anaerobically incubated streak tubes or blood agar plates, surface colonies were 0.5 to $1.0 \mathrm{~mm}$ in diameter, circular with an entire edge, low convex, translucent to semiopaque, gray to white or buff, shiny, and smooth. There was no action on egg yolk agar (6) or on rabbit blood (anaerobically incubated blood agar plates). Cultures did not grow on the surface of blood agar plates incubated in air enriched with

TABLE 3. Fermentation patterns of strains of B. oris and B. buccae for substrates in which strain-to-strain variation was observed ${ }^{\prime \prime}$

\begin{tabular}{|c|c|c|c|c|c|c|c|c|}
\hline \multirow{3}{*}{ Reaction } & \multicolumn{4}{|c|}{ No. of $B$. oris showing indicated reaction } & \multicolumn{4}{|c|}{ No. of $B$. buccae showing indicated reaction } \\
\hline & \multirow{2}{*}{$\begin{array}{c}\text { ATCC } \\
33573 \\
\text { (type) }\end{array}$} & \multicolumn{3}{|c|}{ Other strains } & \multirow{2}{*}{$\begin{array}{r}\text { ATCC } \\
33574 \\
\text { (type) }\end{array}$} & \multicolumn{3}{|c|}{ Other strains } \\
\hline & & + & W & - & & + & W & - \\
\hline \multicolumn{9}{|l|}{ Acid from: } \\
\hline Amygdalin & A & 14 & 1 & 2 & A & 7 & 1 & 3 \\
\hline Arabinose & A & 15 & 0 & 2 & A & $10^{b}$ & 0 & 1 \\
\hline Cellobiose & A & 16 & 1 & 0 & A & 11 & 0 & 0 \\
\hline Esculin & A & 12 & 1 & 4 & - & 6 & 2 & 3 \\
\hline Glycogen & A & 16 & 0 & 1 & A & 11 & 0 & 0 \\
\hline Melibiose & A & 11 & 0 & 6 & - & 11 & 0 & 0 \\
\hline Rhamnose & A & 9 & 0 & 8 & - & 5 & 2 & 4 \\
\hline Ribose & W & 5 & 7 & 5 & - & 3 & 4 & 4 \\
\hline Salicin & A & 16 & 0 & 1 & A & 10 & 0 & 1 \\
\hline Sorbitol & - & 0 & 0 & 17 & - & 0 & 1 & 10 \\
\hline Gelatin digestion & + & 7 & 7 & 3 & + & 6 & 3 & $1^{c}$ \\
\hline
\end{tabular}

${ }^{a}$ Reactions are of the strains used in the homology studies. When multiple strains from the same person gave identical fermentation results, only one strain per person was used in the compilation of reactions. In this table, reactions of the type strain and 17 other strains of $B$. oris and the type strain and 11 other strains of $B$. buccae are reported. Reactions that seemed atypical were repeated several times (with different lots of media). Reactions that were uniformly positive or negative for all strains are given in the species descriptions in the text. -, $\mathrm{pH} 5.7$ or above or no digestion (gelatin); W, pH 5.5 to 5.7 or weak (gelatin); "A" and +, pH below 5.5 or complete digestion (gelatin).

${ }^{b}$ Fermentation of arabinose often varied within four strains of $B$. buccae tested at different times. These four strains were counted as "acid" because fermentation was observed at some time in each.

${ }^{c}$ One strain was not tested. 


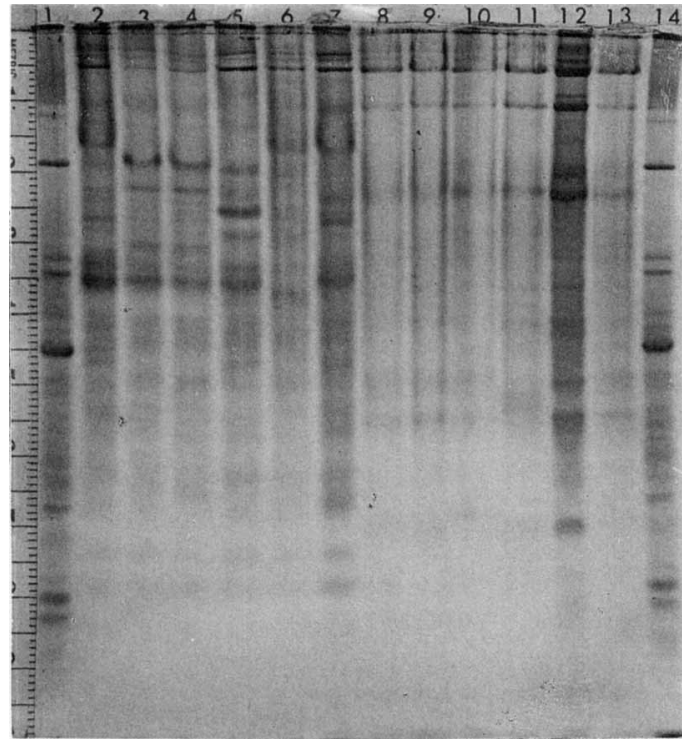

FIG. 1. PAGE patterns of strains of $B$. oris and $B$. buccae. Lanes 1 and 14, Streptococcus faecalis, control strain (VPI U4-20). Lanes 2 to $7, B$. oris: 2, VPI E1H-3 (87\% homology with type strain); 3, VPI D21B16 (89\% homology); 4, VPI D23B-27 (98\% homology); 5, VPI D33A-30 (88\% homology); 6, VPI 10619 (identified by PAGE pattern); 7, VPI D1A-1A (= ATCC 33573 , type strain). Lanes 8 to 13, B. buccae: 8 , VPI D3A-6 (= ATCC 33574, type strain); 9, VPI D54C-6 (86\% homology with type strain); 10 , VPI E1H-22 (88\% homology); 11, VPI 6404 (85\% homology); 12. VPI 11107 (82\% homology); 13, VPI D2B-29B (99\% homology).

carbon dioxide to $10 \%$.

After incubation for $24 \mathrm{~h}$ in prereduced broth media, cultures were uniformly turbid with a smooth sediment. After incubation for 3 to 5 days, the $\mathrm{pH}$ in media containing a fermentable carbohydrate generally ranged as follows: 4.5 to 5.0 in media with carbohydrates fermented by all strains and 5.1 to 5.6 in most media with sugars that were not fermented by all strains (Table 3 ).

All strains fermented cellobiose, dextrin, fructose, glucose, glycogen, lactose, maltose, mannose, raffinose, salicin, starch, and sucrose; all hydrolyzed esculin and starch; all produced an acid curd in milk. None of the strains fermented erythritol, inositol, mannitol, melezitose, or trehalose; none digested milk or meat; none reduced nitrate; none produced indole or catalase. Most strains did not grow in PYG broth containing $10 \%$ bile; when growth in bile did occur, it was markedly inhibited and delayed. Heme was required for growth of the type strain.

Acids produced in PYG broth cultures (in meq/100 ml) were acetic (1 to 2 ) and succinic (4 to 8). Formic acid was detected in cultures of some strains. Very small amounts of isobutyric

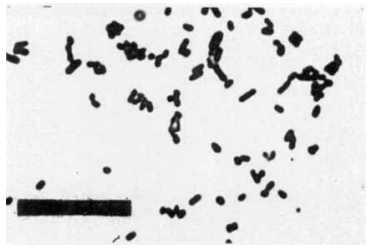

FIG. 2. Photomicrograph of Gram-stained cells from 24-h-old PYG broth culture of $B$. oris VPI D1A1A (= ATCC 33573). Bar represents $10 \mu \mathrm{m}$.

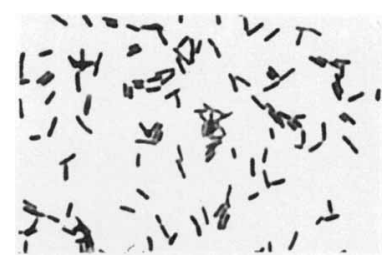

FIG. 3. Photomicrograph of Gram-stained cells from 24-h-old PYG broth culture of $B$. buccae VPI D3A-6 (= ATCC 33574). Magnification is the same as for Fig. 2.

and isovaleric acids were detected in a very few cultures. No hydrogen was detected in the headspace gas from PYG broth cultures.

The type strain and the other strains were susceptible to the test levels of chloramphenicol, clindamycin, erythromycin, penicillin G, and tetracycline; one strain, however, was resistant to $2 \mathrm{U}$ of penicillin $\mathrm{G}$ per $\mathrm{ml}$, and another strain was resistant to $6 \mu \mathrm{g}$ of tetracycline per $\mathrm{ml}$.

The $\mathrm{G}+\mathrm{C}$ content of the DNA of the type strain was $50 \mathrm{~mol} \%$, and the DNA of each of two other strains had a $\mathrm{G}+\mathrm{C}$ content of $52 \mathrm{~mol} \%$.

The type strain, ATCC 33574 (= VPI D3A-6), was isolated from the gingival sulcus of a person with moderate periodontitis.

Strains of this species have been isolated from periodontal flora and other human clinical specimens. In addition to the sources given in Table 1, strains identified by PAGE patterns have been isolated from chest drainages, blood, sinus aspirate (sinusitis), peritoneal fluid, and a specimen labeled "mandibular cyst."

Fermentation of either arabinose or xylose, or both, separated $B$. oris and $B$. buccae from $B$. oralis and strains of $B$. melaninogenicus that produce buff rather than black colonies. $B$. oris and $B$. buccae were more difficult to separate from $B$. ruminicola and from each other. In general, strains of $B$. oris and B. buccae grew much more rapidly and to a higher turbidity than do most strains of $B$. ruminicola. Also, none of the phenotypically similar rumen strains that we have examined shows significant homology with $B$. oris or B. buccae (data not shown). 


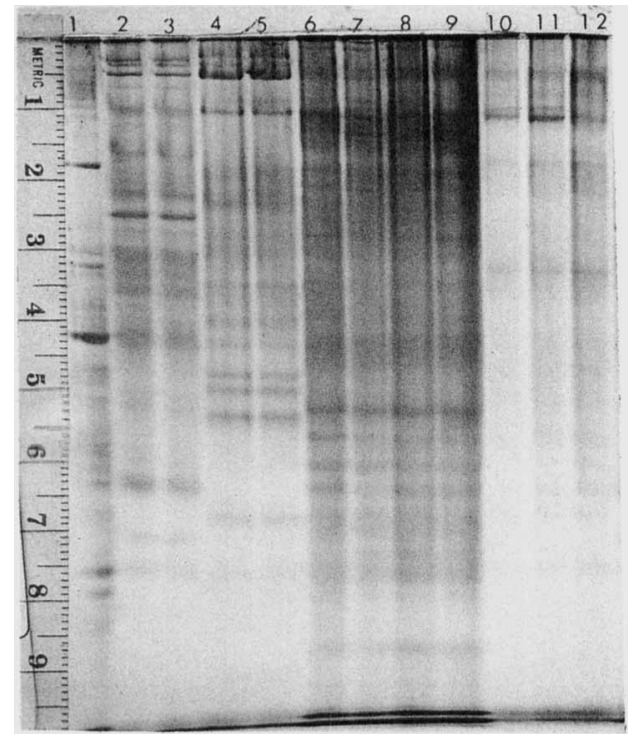

FIG. 4. PAGE patterns of type strains of $B$. oris, $B$. buccae, and $B$. ruminicola. Lane $1, S$. faecalis, control strain (VPI U4-20). Lanes 2 and 3, B. oris ATCC 33573 , brain heart infusion $=0.1 \%(\mathrm{wt} / \mathrm{vol})$ calcium carbonate (BHIC) cultures. Lanes 4 and 5, B. buccae ATCC 33574, BHIC cultures. Lanes 6 to 9, B. ruminicola subsp. ruminicola ATCC 19189: BHIC cultures in lanes 6 and 7, BHIC-10\% rumen fluid culture in lane 8 , heart infusion $-0.2 \%$ fructose-carbonate culture in lane 9. Lanes 10 to 12 , B. ruminicola subsp. brevis ATCC 19188: BHIC cultures in lanes 10 and 11, BHIC-10\% rumen fluid in lane 12 .

B. oris, B. buccae, B. oralis, and B. ruminicola were distinct entities, as determined by DNA homology studies (Table 2) and PAGE patterns of soluble proteins (Fig. 4). Although there was some variation in the PAGE patterns obtained from strains within the species, particularly with strains of $B$. oris, none had a pattern like that of the type strain of $B$. ruminicola subsp. ruminicola, $B$. ruminicola subsp. brevis, or $B$. oralis (pattern not shown). A pair of protein bands at 74 and $78 \mathrm{~mm}$ (lanes 2 to 6 , Fig. 1 [in Fig. 4, they appear at 72 and $76 \mathrm{~mm}$, lanes 2 and 3]) was detected uniformly in strains of $B$. oris and was absent in strains of $B$. buccae. A sharp band at $10 \mathrm{~mm}$ and relatively void areas at 6 to $9 \mathrm{~mm}$ and at 72 to $78 \mathrm{~mm}$ (lanes 8 to 13, Fig. 1 ; lanes 4 and 5, Fig. 4) were distinctive for $B$. buccae.

We do not know of any commonly used phenotypic test that can differentiate these species. It is possible that these species are serologically distinct, but we have not tested this possibility. Because these taxa were determined to be distinct by DNA homology studies and PAGE patterns, we feel that they represent two distinct species.

\section{ACKNOWLEDGMENTS}

We gratefully acknowledge the help of K. Palcanis, R. R. Ranney, and J. A. Burmeister, School of Dentistry, Virginia Commonwealth University, who selected the subjects and sites for periodontal sampling and who obtained the samples. We are especially grateful to T. O. MacAdoo, Department of Foreign Languages and Literature, Virginia Polytechnic Institute and State University, for suggesting appropriate specific epithets and their derivatives. We appreciate the help of D. E. Hash and E. P. Cato in preparing the PAGE gels and the technical assistance of Pauletta C. Atkins, Ann C. Mitchell, and Phyllis V. Sparks.

The work was supported by Public Health Service grants DE-05218, DE-05139 (Virginia Commonwealth University Clinical Research Center for Periodontal Diseases), and DE05054 from the National Institute of Dental Research, Public Health Service grant AI-15244 from the National Institute of Allergy and Infectious Diseases, and project 2022820 from the Commonwealth of Virginia.

\section{REPRINT REQUESTS}

Address reprint requests to: L. V. Holdeman, Department of Anaerobic Microbiology, Virginia Polytechnic Institute and State University, Blacksburg, VA 24061.

\section{LITERATURE CITED}

1. Bryant, M. P., I. M. Robinson, C. Bouma, and H. Chu. 1958. Bacteroides ruminicola $n$, sp. and the new genus and species Succininimonas amylolytica. Species of succinic acid-producing anaerobic bacteria of the bovine rumen. J. Bacteriol. 76:15-23.

2. Crosa, J. H., D. J. Brenner, and S. Falkow. 1973. Use of single-strand-specific nuclease for analysis of bacterial and plasmid deoxyribonucleic acid homo- and heteroduplexes. J. Bacteriol. 115:904-911.

3. Cummins, C. S., and J. L. Johnson. 1971. Taxonomy of the clostridia: wall composition and DNA homologies in Clostridium butyricum and other butyric acid-producing clostridia. J. Gen. Microbiol. 67:33-46.

4. Evans, F. O., Jr., J. B. Sydnor, W. E. C. Moore, G. R. Moore, J. L. Manwaring, A. H. Brill, R. T. Jackson, S. Hana, J. S. Skaar, L. V. Holdeman, G. S. Fitz-Hugh, M. A. Sande, and J. M. Gwaltney, Jr. 1975. Sinusitis of the maxillary antrum. N. Engl. J. Med. 293:735-739.

5. Holdeman, L. V., E. P. Cato, J. A. Burmeister, and W. E. C. Moore. 1980. Descriptions of Eubacterium timidum sp. nov., Eubacterium brachy sp. nov., and Eubacterium nodatum $\mathrm{sp}$. nov. isolated from human periodontitis. Int. J. Syst. Bacteriol. 30:163-169.

6. Holdeman, L. V., E. P. Cato, and W. E. C. Moore (ed.). 1977. Anaerobe laboratory manual, 4th ed. Anaerobe Laboratory, Virginia Polytechnic Institute and State University, Blacksburg, Va.

7. Holdeman, L. V., and W. E. C. Moore. 1974. Genus I. Bacteroides Castellani and Chalmers 1919,959 , p. 385 404. In R. E. Buchanan and N. E. Gibbons (ed.), Bergey's manual of determinative bacteriology, 8 th ed. The Williams \& Wilkins Co., Baltimore.

8. Johnson, J. L. 1981. Genetic characterization, p. 450-472. In P. Gerhardt (ed.), Manual of methods for general microbiology. American Society for Microbiology, Washington, D.C

9. Johnson, J. L., and C. S. Cummins. 1972. Cell wall composition and deoxyribonucleic acid similarities among the anaerobic coryneforms, classical propionibacteria, and strains of Arachnia propionica. J. Bacteriol. 109:10471066.

10. Loesche, W. J., S. S. Socransky, and R. J. Gibbons. 1964. Bacteroides oralis, proposed new species isolated from the oral cavity of man. J. Bacteriol. 88:1329-1337.

11. Marmur, J. 1961. A procedure for the isolation of deoxy- 
ribonucleic acid from microorganisms. J. Mol. Biol. 3:208-218.

12. Marmur, J., and P. Doty. 1962. Determination of the base composition of deoxyribonucleic acid from its thermal denaturation temperature. J. Mol. Biol. 5:109-118.

13. Moore, W. E. C., D. E. Hash, L. V. Holdeman, and E. P.
Cato. 1980. Polyacrylamide slab gel electrophoresis of soluble proteins for studies of bacterial floras. Appl. Environ. Microbiol. 39:900-907.

14. Wilkins, T. D., and T. Thiel. 1973. A modified broth-disk method for testing the antibiotic susceptibility of anaerobic bacteria. Antimicrob. Agents Chemother. 3:350-356. 